\title{
THE CONTRIBUTIONS OF CJEU IN THE NAME OF THE PRINCIPLE OF BALANCING - A TEST OF THE ROLE OF THE COURT? Gina ORGA-DUMITRIU
}

\author{
"Lucian Blaga" University, Sibiu, Romania \\ ginadumitriu@yahoo.com
}

\begin{abstract}
From the traditional functions of the general principles of the EU law - of interpretation, completion of the gaps and legality control, the principle of balancing seems to meet the most the exigencies of the first of these. The limits of the role of CJEU are certainly put to the test when it is called to settle conflicts between fundamental rights/fundamental freedoms. The trends formulated in Schmidberger (on the conflict between the free circulation of the commodities and the freedom of expression) or Promusicae (on the conflict between the right to the effective protection of the intellectual property and the right to the respect of the private life and the protection of the personal data) are more than illustrative. The doctrine assessments of the action of this principle reflect three fields in which the applicability thereof tends to reserve to the Court a role that is susceptible of creating controversies on its traditional extension. According to the authorized voice of Professor Norbert Reich, the balancing in the jurisprudence on the abusive clauses, the balancing for the avoidance of excessive protection and the balancing in social conflicts (making visible an aggravation of the conflict between fundamental rights and fundamental freedoms) are concerned.
\end{abstract}

Keywords: principle of balancing, fundamental rights, fundamental freedoms, unfair terms

I. From the private law principles of the European Union to the principle of conciliation

Doctrinaire evaluations on the recognition of some private law principles of the European Union. In an innovating approach, after the interventions of the Court of Justice of the European Union (CJEU) have contributed to the consolidation of the general principles of the European Union law, and the provisions of the Charter of the Fundamental Rights of the European Union (the Charter) consecrated not only rights and freedoms, but also made an express reference to principles, the identification and promotion of principles of EU Civil Law are attempted today. In the doctrinaire formula proposed by professor N. Reich, the existence of 7 principles [1] is spoken about, principles whose different content is the consequence of the particular origin and functions thereof.

The first 3 principles - the principle of "framed" autonomy, the principle of protection of the weaker party and the principle of non-discrimination are already a part of substantive EU law, governing especially the field of contracts. The fourth principle - the principle of effectiveness is (the same of the principle of equivalence) an older acquaintance of EU law and aims at procedural order aspects, being possible to be also extended to cover substantive and remedial matters. 
The principle of balancing, respectively of proportionality, have a preponderantly methodological dimension: the first is related to the judicial interpretation and application of EU civil law, and the other one related to political-legal significances of some future legislative interventions of the Union in the civil matter (taking the form of a codified or optional instrument), with particular reference to a Common European Sales Law (CESL). Finally, the good faith may substantiate an appearing principle or, also in the hypothesis that the value of principle would not be recognized to it in the current stage of development of the private law of the Union, there are elements suggesting to us that, in the future, it could develop into a more coherent principle, in reference to the future course of EU civil law, especially of the case law of the CJEU [2].

Principle of conciliation - utility and field of application. The application of the provisions of Article 52 (on the scope and interpretation of rights and principles) and Article 54 (on the prohibition of abuse of rights) in the Charter does not exclude the existence of conflicts between "rights" or "principles" of the Charter whose legitimate protection is claimed. In order to provide a balance between the different rights and freedoms recognized within the meaning of EU law, the interpretation thereof is subordinated to the method of conciliation of the protected interests, but situated on contradictory positions. The constitutional value for EU law of the principle of balancing can thus be spoken about, implicitly deduced from the provisions of Article 52 and 54 Charter, the action thereof being also extended over the relations pertaining to the private law of the EU.

Expert voices identify three fields in which the principle of balancing has found specific forms of manifestation: the so-called argument of the price in the control of unfair terms in the consumer credit contracts, within the meaning of Directive 93/13; the apparently paradoxical and incoherent development of some (general) principles of civil law against a potential ,overprotection" of the disfavoured parties and the conflict of the notion of collective autonomy as fundamental right in the work relations in the EU with the provisions in the Treaty on the free circulation [3]. Our attention will be oriented towards the latter area which proved, at least in our opinion, susceptible of the most acute tensions and controversies.

II. Use of the principle of conciliation in the conflict between the fundamental freedoms and the fundamental rights \$1. Orthodox interventions of the Court of Justice of the European Union in the name of conciliation: "the victory" of the fundamental rights?

Interpretations of the Court in Schmidberger. Briefly reiterating the state of fact, we retain that the Austrian authorities allowed to an ecologist group (Austria Tirol Transitforum association) to organize on Brenner highway a demonstration against the pollution of the Alps due to the heavy traffic on the highway; the effect was the closure of the highway for almost 30 hours, the highway being the main route of transit between Germany and Italy. Plaintiff Schmidberger a transportation company established in Germany, whose main scope of business is represented by the transport of gods (wood) from Germany to Italy, filed an action claiming damages from the Austrian authorities and mainly invoking that the closure of the highway represents a restriction of the free circulation of the commodities. The Austrian national Court formulated a reference for a preliminary ruling of the provisions in the treaty forbidding the measures having an effect equivalent to the quantitative restrictions and those on the exceptions from the free movement of goods. The Court examined whether the restriction from the free movement of goods allowed by the Austrian government was justified by the protection of the freedom of expression and the freedom of assembly and association 
consecrated by Article 10 and 11 of the European Convention on Human Rights (ECHR).

Thus, Schmidberger jurisprudence [4] brings into discussion the conflict between two principles - the protection of the free movement of goods, respectively the protection of the right/freedom of assembly and association or, in other terms, between a fundamental freedom and a fundamental right. The interpretations of the Court aim at the manner of settlement of this conflict in the context in which the constitutional value (of the freedom, of the respective fundamental right) is an equal one.

Practically, it is the first case in which a restriction of a fundamental freedom is justified by the necessity of protection of fundamental rights. After having reiterated that the fundamental human rights represent an integral part of the principles of EU law and referred to Article 6 (2) in TEU [5], the Court reckoned that the protection of the fundamental rights is a legitimate interest, which, in principle, justifies a restriction of the obligations imposed by the community law, even in the case of a fundamental freedom, such as the free movement of goods. It needs to be retained that the exceptions must be interpreted restrictively; if a Member State has the possibility to choose between several measures for the accomplishment of the same purpose, it has to choose the means least restricting the fundamental freedoms. In another train of thoughts, the judgment is relevant because, the supremacy originating from another law source in reference to EU law is implicitly accepted (upon the passing thereof).

The reasoning promoted in Schmidberger was generally well received, being confirmed, with particular reference to the conflict between the free movement of goods and the freedom to provide services and the protection of human dignity, also by judgment subsequently passed in Omega [6]. We cannot say the same thing about the solutions passed in Viking and Laval too, which raised the problem of the impact of the freedom of establishment and of the freedom to provide services on the protection of the workers, more precisely on the limits of development of the actions of the trade union organizations for the protection of the workers in cross-border situations.

\$2. Controversial interventions of the Court of Justice of the European Union in the name of conciliation: the "victory" of the fundamental freedoms?

Interpretations of the Court in Viking and Laval. General appraisal. In Viking [7] and Laval [8], the test of conciliation is used by the judge on Kirchberg plateau in order to settle the conflict between the freedom of establishment, respectively the freedom to provide services and the fundamental social rights, more precisely the right to collective negotiations and the right to collective actions. The approach of the Court triggered intense debates and critical appraisals, aggravating the tensions. It has been stated that the passed solutions would summarize the dilemma on social Europe or the free trade Europe? («Europe social ou Europe du libre échange ?») [9] that unfavorable today to the social interests, the Court of Justice of the European Union loses its appearance of impartiality [10] or that the judgments would have ruined the policies of the Member States regarding the minimum wages or that they would have degraded the value of the trade union rights.

But which are the concrete circumstances having caused these litigations?

Argumentation of the Court in Viking. Resuming the state of fact, Viking, a company established under the Finnish law and ferry transport operator intended to change the Finnish flag (into Estonian flag) of one of the shops it exploited (Rosella) which provided the sea route between Tallinn (Estonia) and Helsinki (Finland); its option was the consequence of the deficient exploitation of Rosella ship because of the direct competition with the Estonian ships which provided the same route in exchange 
for lower salary costs (concretely, the salaries paid to the Estonian crews were lower than the salaries of the Finnish crews). Its intentions were faced with the opposition of the Finnish sailors' trade union (FSU), affiliated to an international federation of trade unions of the workers in the field of transports (ITF) reuniting 600 trade unions 140 different states. Following the requests of FSU, ITF sent a circular letter to all the affiliated trade unions, requesting them not to negotiate with Viking, as the actual ownership of Rosella ship is in Finland and that FSU maintains the right of negotiations with Viking. One of the policies constantly promoted by ITF is the fight against the ,flags of convenience", a ship being registered under such a flag when the actual ownership and control of the ship is in another State but the one of the flag under which it is registered. Or, according to the policy of ITF, only the trade unions established in the state in which the actual owner of a ship is are entitled to conclude collective agreements regarding this ship.

After the expiry of the collective agreement applicable to the crew of Rosella ship, FSU initiated a strike, in order to prevent the change of flag, the circular letter of ITF continuing to produce its effects. Consequently, Viking invested the High Court of Justice, Queen's Bench Division with an action for the termination of the illegal actions of FSU and ITF as being contrary to the provisions on the Treaty on the freedom of establishment.

In the answers to the preliminary questions, the Court, although admitting that the right to take a collective action, including the right to go on strike, must be recognized as a fundamental right representing an integral part of the general principles of Community law, retains that the exercise thereof may be subject to restrictions when the strike is contra bonos mores or is prohibited under national law or Community law [11]. Consequently, it reckons that a collective action initiated by a trade union or a group of trade union against an enterprise, in order to determine it to concluded a collective convention whose content may discourage it to exercise the freedom of establishment is not excluded from the field of application of the provisions of Article 43 EC (the current Article 49 TFEU). It is the first step towards the more "liberal" discourse in favour of the economic freedoms and a breach for the "social" one of the workers' fundamental rights.

Moreover, the Court is visibly more willing than Schmidberger to use the test of proportionality in favour of the right of establishment and resorts to the test of conciliation when it highlights that the provisions of the Treaty on the free movement of goods, persons, services and capitals must be balanced with the objectives pursued by social policy, among which, pursuant to Article 136 the first paragraph EC (the current Article 151 TFEU) the improved living and working conditions is especially noted [12]. According to the reasoning exposed in Schmidberger, the protection of the fundamental rights constitutes a legitimate interest capable of justifying, in principle, a restriction on the obligations imposed by the Community law, even within the meaning of a fundamental freedom (such as the one on the free movement of gods).

After stating that the collective action of FSU and the boycott ones of ITF make less attractive and even non-useful the exercise by Viking of its right of free establishment, having the character of restrictions on the freedom of establishment. Consequently, it is going to establish whether these restrictions (concretely the collective action) aim at a legitimate goal compatible with the Treaty, whether they are justified by imperative reasons of general interest and, especially, if they do not exceed what is necessary in order to accomplish this goal. The approach of the Court of Justice of the European Union is different, in this respect from the one of the European Court of Human Rights. The reasoning is 
reversed: the European Court of Human Rights verifies whether the restrictions of the right to go on strike are justified, the Court of Justice of the European Union verifies whether the restrictions on the right of establishment are justified. It is the place where the doctrine identified a legal activism of the Court and even the application contra legem of Article 137 point 5 EC Treaty (currently Article 153 TFEU). This article does not include the right to strike in the general competences of the Community. But the reasoning of the Court is the following: the European Community becomes competent in case these rights overlap another community competence [13].

Although it recognizes to the Court of reference the prerogative of passing a judgment on the justified character of the collective action as a restriction of the freedom of establishment, the Court formulates some criteria in reference to which this appraisal would be made, criteria considered by us additional restrictions on the right to strike. Thus, even if the collective action of FSU could be reasonably considered, at first sight, within the objective of protecting workers, such a view would no longer be tenable if it were established that the jobs or conditions of employment at issue were not jeopardised or under serious threat [14]. Moreover, further on, the Court even identifies such a circumstance, namely when the company with the changed flag would be held by a collective agreement guaranteeing to the workers the preservation of the provisions of the collective convention governing the work relation. Or, returning to the state of fact, Viking has already committed within a conciliation procedure that the change if flag would not result in any layoff.

The Court seems even more militant when (though leaving it all up to the Court of reference to pass a judgment) it formulates appraisals on the appropriate and proportional character of the restrictions to the freedom of establishment, with particular reference to the solidarity actions of ITF. Thus, to the extent to which the policy adopted by ITF results in shipowners being prevented from registering their vessels in a State other than that of which the beneficial owners of those vessels are nationals, the restrictions on freedom of establishment resulting from such actions cannot be objectively justified [15]. The preoccupation for the guarantee of the exercise of the establishment is visible and is done with the cost of the irritation of the right to collective solidarity actions (taken in the case by ITF). Practically, the Court takes over the thinking line expressed by the opinion of Maduro General Advocate, who, after retaining that he is going to make a distinction between the collective action to persuade an undertaking to maintain its current jobs and working conditions and the collective action to prevent an undertaking from providing its services once it has relocated abroad [16]. The first is a legitimate means recognized to the workers, whereas the prevention or the threat of prevention, by means of a collective action, of an enterprise established in a Member State to provide its services in another Member State is the type of commercial obstacle identified by the Court as incompatible in the Commission v. France [17]. However, this assimilation is not actually the most appropriate. In the quoted jurisprudence, although the breach of the free movement of goods was the result of the actions of private individuals (the deeds of vandalism of the French agricultural workers who destroyed the vegetables and fruit originating from other Member States), the inaction of the State, that manifested passivity and did not repress these behaviours was considered a breach of the obligations undertaken by the Treaty. Or, in Viking, the inactivity of a Member State which fails to take the measures necessary to remove the obstacles for the freedom of establishment is not concerned, but only the actions of some private entities susceptible of restraining the freedom of establishment. 
Laval fast confirms the solution in

Viking. The solution passed in a very short time in Laval animated the debates even more and proved to is that this conciliation between the exercise of the trade union rights in the EU and the fundamental freedom (with particular reference to the freedom to provide services now) becomes more and more difficult. Moreover, this statute of the CJEU of arbitrator of the economic freedoms in conflict with the social rights seems to have much more extended stakes, in the sense of wondering whether it does not exceed its traditional role of exercise of the interpretative function of the Treaty and of other regulations passed by the Union law-maker. Laval, a Latvian law firm established in Riga seconded to Sweden 35 Latvian workers in order for them to work on the construction sites of Baltic, a company established under the Swedish, in view of the construction of a school in Vaxholm. As these employees were not paid according to the wage-payment terms established by the Swedish collective work agreements in the field of constructions, the Swedish trade union of the workers in the field of constructions resorted to the blocking of the construction site of Vaxholm (by the prevention of the delivery of goods to the construction sites, the installation of strike pickets and the forbiddance of the Latvian workers to enter the construction site). Subsequently, the collective actions against Laval intensified, the Swedish trade union of the electrician workers (Elektrikerna) initiating a solidarity action which resulted in the prevention of the Swedish enterprises to provide services to Laval. Moreover, other trade union organizations also boycotted the construction sites owned by Laval in Sweden, which prevented the company from continuing to exercise its activities on the territory of this state.

The passed solution confirms the conception also promoted in Viking, extended this time in terms of the freedom to provide services. The Court concludes inter allia that Articler 49 EC (the current Article 56 TFEU) and Article 3 in Directive $96 / 71$ on the secondment of the workers within the service supply must be interpreted in the sense that they are opposed to the possibility for one collective organization to try to constrain, by a collective action taking the form of the blocking of construction sites, as the one in the main action, a service provider established in another Member State to start a negotiation on the salaries that must be paid to the seconded workers. It was not by change that, after Laval, Figaro titled «l'Europe légitime le dumping social» and the criticism on the facilitation of the exploitation of the workers in the countries in which they are paid less or are less protected has become more and more corrosive [18]. Would a failure of conciliation also be concerned?

§3. Secondary benefit of the exercise of the conciliation in Viking and Laval. Getting overt this rhetoric of the conflict, which would be, however, the plus-value elements of the interpretations of the Court, the horizontal effect of the provisions on the freedoms of circulation [19] and the opposability thereof also towards private individuals remains, which does not mean, as AG Maduro warned, the end of the private autonomy thereof, nor that the private operators should comply with the same standards imposed to the public authorities.

\section{References \& Bibliography}

[1] See N. Reich, General Principles of EU Civil Law, Intersentia, Cambridge, 2013, p. 16 and the considerations formulated on the work by the review elaborated by G. OrgaDumitriu, in Romanian Review of European Law no. 1/2015.

[2] See N. Reich, op. cit., p. 16. 
[3] Ibidem, p. 133.

[4] CJEC, 12 June 2003, case C-112/00, Eugen Schmidberger, Internationale Transporte und Planzüge v Republik Österreich, ECR 2003, p. I-5659

[5] According to the quoted provisions „The Union shall accede to the European Convention for the Protection of Human Rights and Fundamental Freedoms (...)".

[6] CJEC, 14 October 2004, case C-36/02, Omega Spielhallen-und AutomatenaufstellungsGmbH v Oberbürgermeisterin der Bundesstadt Bonn, ECR 2004, p. I-9609.

[7] CJEC, 11 December 2007, case C-438/05, International Transport Workers' Federation and Finnish Seamen's Union v Viking Line ABP and OÜ Viking Line Eesti, 2007 I10779

[8] CJEC, 18 December 2007, case C-341/05, Laval un Partneri Ltd v Svenska Byggnadsarbetareförbundet, Svenska Byggnadsarbetareförbundets avdelning 1 , Byggettan and Svenska Elektrikerförbundet, ECR, 2007, p. I-11767.

[9] See http://www.eurogersinfo.com/actu5507.html, Arrêts Laval et Viking: la délicate conciliation $d u$ droit syndical et des libertés d'établissement et de prestation de services.

[10] See E. Alt, Echilibrul dintre drepturile economice şi sociale în jurisprudenţa Curţii de Justiţie a Comunităţilor Europene (translation by Dragoş Călin) in Forumul Judecătorilor no. 2/2009, p. 113, available at http://www.forumuljudecatorilor.ro/wpcontent/uploads/Art-14-Forumul-judecatorilor-nr-2-2009.pdf.

[11] See paragraph 44 of Viking.

[12] Idem, paragraph 79.

[13] See E. Alt, op. cit., p. 111.

[14] See paragraph 81 of Viking.

[15] Idem, paragraph 88.

[16] See Opinion of Advocate General Poiares Maduro, 23 May 2007, paragraph 67, available at http://curia.europa.eu.

[17] CJEC, 9 December 1997, case C-265/95, Commission of the European Communities $v$ French Republic, ECR 1997, p. I-6959.

[18] See E. Alt, op. cit., p. 113.

[19] See G. Busseuil, Contribution à l'étude de la notion de contrat en droit privé européen, LGDJ, 2009, nº 231, p. 246. 